\title{
Tullock challenges: happiness, revolutions, and democracy
}

Frey, Bruno S

\begin{abstract}
Gordon Tullock is one of the most important of the founders and contributors to Public Choice. Two innovations are typical "Tullock Challenges." The first relates to method: the measurement of subjective well-being, or happiness. The second relates to digital social networks, such as Facebook, Twitter, and to some extent Google. Both innovations lead to strong incentives by governments to manipulate the policy outcomes. In general, "What is important will be manipulated by the government." To restrain government manipulation, one has to turn to Constitutional Economics and increase the possibilities for direct popular participation and federalism or introduce random mechanisms.
\end{abstract}

DOI: https://doi.org/10.1007/s11127-011-9821-z

Posted at the Zurich Open Repository and Archive, University of Zurich ZORA URL: https://doi.org/10.5167/uzh-52470

Journal Article

Originally published at:

Frey, Bruno S (2011). Tullock challenges: happiness, revolutions, and democracy. Public Choice, 148(34):269-281.

DOI: https://doi.org/10.1007/s11127-011-9821-z 
First Tullock Lecture

European Public Choice Conference

Rennes, 28 April - 1 May 2011

\title{
TULLOCK CHALLENGES: HAPPINESS, REVOLUTIONS AND DEMOCRACY
}

\author{
Bruno S. Frey* \\ University of Zurich, \\ University of Warwick \\ and
}

CREMA - Center for Research in Economics, Management and the Arts, Switzerland.

\begin{abstract}
Gordon Tullock has been one of the most important founders and contributors to Public Choice. Two innovations are typical "Tullock Challenges". The first relates to method: the measurement of subjective well-being, or happiness. The second relates to digital social networks such as Facebook, Twitter, or to some extent Google. Both innovations lead to strong incentives by the governments to manipulate the policy consequences. In general "What is important, will be manipulated by the government". To restrain government manipulation one has to turn to Constitutional Economics and increase the possibilities for direct popular participation and federalism, or introduce random mechanisms. (99 words)
\end{abstract}

Keywords: Happiness, social networks, constitutional economics, random mechanisms, public choice

JEL Classifications: D72, H10, I31, P16, D02

Department of Economics, University of Zurich, Wilfriedstrasse 6, CH-8032 Zurich, Switzerland. E-mail: bruno.frey@econ.uzh.ch I am grateful to Reto Cueni, Jana Gallus, Stephan Kyburz, Maik Meusel and Lasse Steiner for helpful comments. 
Gordon Tullock has without any doubt been one of the most vibrant and important founders and contributors to Public Choice. Everyone who ever met him must have been impressed by his gift to immediately engage everyone into high level scholarly arguments - which, in most if not all cases, the other person lost. Almost always, Gordon Tullock would propose a totally unconventional idea and make a wild policy suggestion. He is a real "innovative sceptic" coming up with "uncommon solutions".

When I first met Gordon he immediately criticized me concerning my "totally naïve view" about the population's influence on politics. In particular, he claimed that there has never been a revolution successfully achieved by the citizens ${ }^{1}$. This was new to me; I was one of those romantic people believing in revolutions from below.

Knowing that I come from Switzerland, Gordon immediately suggested that I should develop a better political system than democracy. I was rather flabbergasted; as most other people, I considered democracy, and in particular direct democracy, to be a sanctified institution. I did not have a clue how to improve on it.

I greatly enjoyed these interactions with Gordon. They motivated me to think hard about these challenges but I must confess that I am far from Gordon's originality in suggesting solutions. As I greatly admire Gordon, it is a great honour for me to have been chosen by the Board of the European Public Choice Society to present the First Tullock Lecture.

I call "Tullock Challenges" open issues identified by the kind of thinking Gordon represents. I choose two innovations - as far as I am aware - Gordon did not deal with because they are quite recent. The first innovation is one of method: it has become possible to measure subjective well-being, or happiness. It is one of the noteworthy results of modern happiness research to demonstrate that such measurements make sense and are reliable. The possibility to measure happiness has had important policy consequences; countries like France or the United Kingdom now engage in policies designed to maximize happiness.

The second innovation I deal with are the digital social networks such as Facebook, Twitter, to some extent Google, and other internet platforms. The policy consequences may be that revolutions from below appear to be possible now. The examples of Tunisia, Egypt and Libya, as well as other Arabic countries and beyond, may point in this direction.

The challenge is to understand what consequences these two innovations have for society and what political measures can be used to make them beneficial for the people. While the two innovations are on a quite different level, there is nevertheless a common theme. I will argue that both innovations lead to strong incentives by the governments to influence the policy consequences. Indeed, I propose that "What is important, will be manipulated by the government". Thus, I claim that governments will manipulate the happiness indicators and the digital social networks in their favour. This is a generalization of the well-known result from Social Choice Theory that all preference aggregations can be manipulated.

Section I discusses the effect on politics of the innovation to measure happiness, and section II of the innovation of digital social networks. Section III inquires what can be done to mitigate or prevent manipulation by government and to help fulfil individual preferences. I will argue that we have to turn to Constitutional Economics ${ }^{2}$ and increase the possibilities for direct popular participation and introduce random mechanisms. Section IV closes by considering what Gordon Tullock teaches us with respect to these issues.

\footnotetext{
${ }^{1}$ See Tullock 1971, 1974, 1987. Public Choice contributions influenced by Tullock's lead are for example Bernholz 1991, 1997, Wintrobe 1998, Kurrild-Klitgaard 2000.

${ }^{2}$ This is, of course, another major contribution by Gordon; see the major influence of

Buchanan and Tullock's (1962) book.
} 


\section{The Happiness Innovation}

\section{A. Measuring subjective well-being}

Human beings want to be happy: this is the view most philosophers share. In particular, Aristotle stressed that happiness is a desirable goal of most people in all periods. The innovation thus does not relate to happiness as such but to the possibility of measuring it in a reliable way. Economists have traditionally assumed that utility cannot be measured. As a consequence, microeconomics was developed without the need to measure utility. Rather, it is assumed that individuals maximize their utility subject to constraints, which yields empirically testable propositions. In contrast, psychologists have for a considerable number of years measured happiness by carefully administered representative surveys. Only recently ${ }^{3}$ economists have noted this innovation and have started to use the corresponding data ${ }^{4}$. These data are of good quality and can be used for serious econometric estimates. In particular, measured subjective happiness correlates highly and robustly with objectively measurable aspects most people associate with "true" happiness such as that happy people smile more, initiate more social interactions, are more energetic, flexible, creative and optimistic, and are less prone to commit suicide.

Most studies in economics use "life satisfaction" based on carefully administered representative surveys ${ }^{5}$ capturing a longer run and cognitive self-evaluation of subjective well-being. In contrast, "happiness" relates to a short run, affective mode. However, in line with much of the scholarly literature, I use the terms "happiness" and "life satisfaction" interchangeably as long as no confusion arises.

Today, happiness research has become a thriving field ${ }^{6}$. Interdisciplinarity is one of its major characteristics. In addition to psychologists and now economists, there are political scientists and sociologists involved in the field. The techniques of analysis are quite similar so that there is more extensive cross-fertilization than in most other areas of scientific inquiry. Arguably, European contributions are as important, if not more important, than American ones.

\section{B. Determinants of Happiness}

Some of the most important determinants of happiness are also relevant for policy. These factors refer to the simultaneous estimates and are similar for a large number of countries, quite irrespective of their income level. The results listed are marginal effects keeping all other influences constant.

Economic determinants:

- Higher income clearly produces more happiness but at a strongly decreasing marginal rate;

- The unemployed are much less happy than are those having a job;

- The self employed are happier than those working as employees despite the fact that they tend to work longer hours, carry more risk, and often earn less.

- Giving and voluntary work raise the happiness of those engaging in these activities.

\footnotetext{
${ }^{3}$ A forerunner is Easterlin 1974.

${ }^{4}$ Examples are the General Social Survey, the European Social Survey, the German SocioEconomic Panel, the British Household Panel, or the World Gallup Poll.

${ }^{5}$ Representative surveys are only one technique to measure subjective well-being. Other techniques are e.g. the Experience Sampling Method, the Day Reconstruction Method, the UIndex, or brain scanning.

${ }^{6}$ See e.g. the survey articles by Oswald 1997, Frey and Stutzer 2002a, Dolan et al. 2008; and the monographs by Kahneman et al. 1999, Frey and Stutzer 2002b, van Praag and Ferrer-iCarbonell 2004, Layard 2005, Frey 2008.
} 


\section{Social determinants:}

- Religious persons are happier than those not believing in God or in a higher power, and not attending religious ceremonies;

- Family;

- Personal relationships in the form of having friends and entertaining many social contacts raise happiness.

\section{Political determinants:}

- People are happier in democratic polities; they value the political participation possibilities in a constitutionally guaranteed process above and beyond outcomes (they reap procedural utility).

- The more decentralized the political decisions, i.e. the closer they are to the citizens, the happier people are.

- "Good government" contributes to happiness.

Psychological effects:

- Human beings evaluate their own happiness level relative to other persons. They compare themselves to reference groups endogenously chosen. In particular, when individuals experience higher income, they compare themselves to other persons whose income also might have risen.

- People adapt to new circumstances. In the extreme, this leads to the "Easterlin Paradox" suggesting that economic growth does not raise happiness as people continually and fully adjust their expectations upwards.

\section{Policy Conclusions}

Based on the insights from happiness research, a number of prominent scholars, such as Robert Frank, Richard Layard or Andrew Oswald, but also politicians such as French President Sarkozy, British Prime Minister David Cameron, as well as the People's Republic of China, conclude that governments should use these results to "maximize happiness". Even earlier, the Kingdom of Bhutan decided to maximize Gross National Happiness instead of Gross National Product (see Ura and Galay 2004).

A number of concrete policies have been suggested but it suffices here to mention two of them to capture their gist.

- Due to the insight of happiness research that individuals tend to compare themselves to others, those experiencing an income increase impose a negative external effect on other persons. This produces a rat race in which nobody is better off despite investing much effort to keep up with the Joneses. Scholars such as Frank (1999) and Layard (2007) propose to (heavily) tax these external effects by equalizing incomes.

- Unemployed persons are much less happy than employed ones but this effect is mitigated when the unemployed live in areas in which many other persons are unemployed. It follows that a happiness maximizing policy should focus on areas with little unemployment as it is there where people feel the most unhappy. It follows that policy makers should be less bothered by the pockets of high unemployment, as people there are less unhappy than those in areas with little unemployment.

\section{Arguments against the government maximizing happiness}

There are various sets of arguments why governments should not pursue the goal of maximizing an index representing people's happiness. They have been expounded in Frey and Stutzer (2010) and need not be repeated here. In the context of the "Tullock Challenges" the major counterargument against government maximizing happiness is that it will manipulate the happiness index. 
Proposition 1: As soon as the happiness index has become an official goal of government policy, the government will manipulate it.

Such behaviour is not surprising - at least to a political economist - but it has nevertheless been largely disregarded when it comes to government policy. In the social sciences a similar idea is known as Campbell's Law (1976) stating that the more intensively a quantitative indicator is used for policy purposes, the stronger it is subject to distorting and biasing social processes. In economic theory, the informational aspect has been pointed out in Goodhart's Law (1975). It suggests that once an economic indicator, in particular the stock of money, is made an economic policy target, it will lose the information content that would qualify it to play such a role. The Lucas Critique (1976) states that the structure of an econometric system tends to break down when policy interventions are undertaken. Power (1997), Strathern (2000) and Osterloh and Frey (2010) analyze the reactivity of persons when they are subjected to audits, rankings, and other assessments. Jacob and Levitt (2003) show that schools subject to standardized tests give them incentives to cheat, such as "teaching to the test", or excluding weak students from attending when the test takes place, or excluding them from the school altogether. Espeland and Saunders (2007) empirically study the response of American business schools to their rankings undermining their usefulness. All this reminds of the fundamental problem in preference aggregation that all democratic voting schemes that purport to choose a winner from at least three candidates can be manipulated (Gibbard 1973, Satterthwaite 1975, for a recent account Szpiro 2010). However, in contrast to the above proposition, social choice theory does not focus on a particular actor's incentives to manipulate.

Governments have for a long time influenced aggregate policy indicators, or used "creative accounting" in their favour (see e.g. the evidence in von Hagen and Wolff 2006, Dafflon and Rossi 1999, Forte 2001). Many different governments have manipulated the size of GNP by introducing parts of the shadow economy into the official measure, or by just assuming particular changes in the productivity of the public sector. During the recent Euro-crisis, several governments have demonstrated that budget deficits and the size of the public debt can be easily utilized for one's own purpose. The possibilities to manipulate the happiness index are considerably larger than for public sector indicators because it is based on representative surveys of subjective evaluations. It is quite easy to distort representativeness in favour of the government, e.g. by excluding unhappy persons who are difficult to reach (such as the homeless). The index can also be manipulated by excluding or including persons only staying in the country for a limited time period, who are defined to be "mentally ill", or who are incarcerated. Outliers, e.g. persons stating that their life satisfaction is "abysmally low", can be excluded by arguing that their answers are not to be taken seriously. In fact, governments exhibit a great amount of ingenuity to manipulate indicators in their favour.

Even if for some reason it was not possible or suitable to manipulate the existing happiness index, governments have a way out. They can introduce a new happiness indicator claiming that it captures the relevant or "true" happiness of the population in a better way. In actual fact they introduce it because it is more favourable to the politicians in power. For instance, a new happiness indicator can be constructed giving more weight to people with low income, or with unfortunate life experiences, provided the government believes to be able to increase their happiness and to therewith demonstrate that it is successful.

\section{F. Consequences}

What is important will be manipulated. Politicians pursuing their own goals of personal power, recognition, ideology, and income, and seeking to stay in government, have a strong incentive to manipulate the happiness index they claim to maximize. The result is that such a policy does not correspond to the preferences of the population. Rather, it leads to a 
systematic deviation from this democratic goal, and obfuscates the performance of government. I therefore conclude that governments should not maximize happiness. In section III I try to indicate in what ways government can use the insights of happiness research to improve the lot of the population.

\section{Digital Innovations and Revolutions}

\section{A. Digital Social Networks}

Over the last years, the surveillance by CCTV has expanded rapidly. In some countries such as Italy and the United Kingdom, many people are continually monitored. Google's "street view" goes in the same direction. This raises a government's ability to control its population and to prevent any signs of discontent with its policy.

Internet forums, or "digital social networks" such as Facebook, Twitter, and to some extent Google, as well as Wikileaks are often claimed to be "democratic instruments" helping citizens to regain their position vis-à-vis government. The digital social networks facilitate an exchange of views between a wide set of persons at very low or no entry cost, and are open to anyone. It seems to be close to the philosophical idea of an unconstrained discourse (Habermas 1996). This democratic function has become visible in the revolutions recently taking place in Tunisia, Egypt, and Libya, and the anti-government demonstrations in several other countries including the People's Republic of China.

\section{B. Government manipulations}

Digital social networks are an innovation which does not only serve individuals to express and discuss their opinions but also presents new opportunities for the politicians in power to manipulate information and to control the population.

Proposition 2: Governments have an incentive to manipulate the digital social networks in their favour.

There are four major avenues for governments to exploit the internet innovations to further their own goals (see also Morozov 2010):

- Persons active on the internet do not only interact with other users but can also be identified by the police and secret service. As a consequence the use of these platforms is dangerous.

- Independent suppliers of internet information such as Wikileaks can be haunted, persecuted and silenced and internet providers not conforming to the wishes of the government can be shut down (see Economist February $12^{\text {th }}, 2011$ ).

- Governments can capture the internet by employing professional pro-government bloggers. As a result, the digital social networks are undermined.

- Finally, governments can use the possibilities provided by the internet to divert attention form politics. It can provide attractive films, video clips, sporting events, celebrity news or pornography shows so that the incentive to demonstrate or revolt is decreased or vanishes altogether. There is concrete evidence from the former German Democratic Republic (Kern and Hainmueller 2009) that such "opium for the masses" may indeed work. At that time, parts of the country were able to receive TV channels from West Germany, while other parts did not and could only consume the incessant and boring propaganda from the communist rulers. One would expect that those who every evening could see the far higher living standard and freedom in the West would be more opposed to the GDR government. In fact the opposite was true. East Germans

\footnotetext{
${ }^{7}$ For example by the US government; see Economist Jan $8^{\text {th }}, 2011: 74-5$.
} 
exposed to West German TV were more satisfied with life in East Germany (they, for instance, made fewer applications for exit visas). This seemingly paradoxical result can be attributed to TV primarily being a source of entertainment. Television viewers did not threaten the Communist government because they were too much occupied vicariously consuming the Western life style.

This case suggests that governments may actively use digital platforms to provide entertainment and to dampen political unrest. The idea that "no dictator in the world can stop Facebook" (a recent title in a German newspaper) is naïve - and Gordon Tullock would certainly be one of the first to agree with that verdict. Governments have indeed a strong incentive to manipulate internet innovations.

It could be argued that the recent events in Tunisia, Egypt and Libya indicate that the existing digital social networks helped to topple dictatorial governments. This is true but might be the exception rather than the rule. The means of internet communication are relatively recent innovations and the respective Arab governments were therefore not sufficiently prepared to counter the danger. It may also be argued that these dictatorships were technically and mentally incapable of meeting this challenge. It must, however, be assumed that other authoritarian governments will quickly learn once they realize how dangerous digital social networks can become to them. Moreover, it is not clear whether revolutions based on digital networks are really effective. The activity induced takes place at an individualistic level and reflects "flash campaigns" devoted to ever-new issues. In contrast, the establishment of a new, more democratic, government must be based on a dependable and stable constitutional framework.

\section{New Digital Equilibrium}

Internet fora are an innovation at the same time raising the possibility of individuals to politically express their preferences and of governments to counteract and to influence individuals. It is therefore mistaken to assume that this innovation is a unique force furthering revolutions from below. Gordon Tullock's scepticism with such "romantic" views holds also in the age of digital social networks. Public Choice scholars have the task to analyze the determinants of the new equilibrium driven by the digit innovation. The conditions under which the innovation can be exploited by the individuals and the politicians in power need to be carefully identified. This presents a major challenge.

\section{How to Restrain Government Manipulation?}

\section{A. Independent bodies}

The innovations produced by the ability to measure happiness and to engage in digital social networks enlarges governments' scope to manipulate individual preferences. The only way to check this incentive is to change the rules of the game. One possibility is to establish independent political bodies (see Eichenberger and Schelker 2006). The idea of a judicial branch independent from government is part of the classical division of power. More recently, central banks have been given a status of independence vis-à-vis the government. To prevent the manipulation of the happiness index (as well as of other macroeconomic indicators) one might establish an independent statistical office. To prevent the manipulation of digital social networks one might establish an independent telecommunications agency.

It is doubtful whether bodies can be constructed which are really independent of the government, in particular in countries without such traditions. This even applies for central banks. There are only very few in the world which cannot be forced by the politicians in power to follow their wishes and orders. Governments often manipulate formally independent central banks. Even if the independent bodies are able to maintain their 
discretion with respect to the tasks assigned to them, governments find it easy to circumvent them. A statistical office in charge of the happiness index finds it difficult to prevent governments from introducing a new, more favourable index. A telecommunications agency can hardly prevent governments from interfering in new ways with digital social networks. It is therefore advisable to look into more fundamental constitutional rules to restrict the manipulation of the population by governments. Section B proposes stronger political participation possibilities, and Section $\mathrm{C}$ a more extensive use of random mechanisms.

\section{B. Stronger political participation possibilities}

Authoritarian systems as well as representative democracies are prone to give professional politicians extensive powers. A "political class" emerges which tends to act in its own interest while disregarding the wishes of the population. Empirical research in Public Choice (see in particular Kirchgässner, Feld and Savioz 1999) has demonstrated that extending the popular participation rights of the citizens via initiatives, referenda and recall may considerably restrain government. The same holds for the decentralization of political decisions in traditional federalism and newer forms (such as e.g. FOCJ, see Frey and Eichenberger 1999). These constitutional rules lead to more fully informed and active citizens (as empirically shown by Benz and Stutzer 2004), and to more confident citizens ${ }^{8}$ who are better able to resist government manipulations. They are more aware of a government's intention to modify or exchange the happiness indicator as well as of the extent to which it interferes with the digital social networks.

\section{Random mechanisms}

The use of probabilistic elements in politics can be seen as an extension of democracy. In contrast to a traditional definition of democracy focused on the right to vote, it leads to a closer reflection of individual preferences in political bodies and decisions. It can be considered a disregarded form of government in the tradition of Gordon Tullock.

Random selection mechanisms allow an exact representation of citizens' preferences and undermine the attempts of governments to manipulate their citizens. Moreover, it saves the increasingly large cost of running a voting system consisting in the monetary expenditures for an election campaign, as well as in the attention devoted by reigning politicians and their contenders. Random selection may be used widely: to choose the members of parliament either of one or of both chambers; the executive at the various levels of government; and the judiciary.

Random systems are not totally new. Indeed, in antiquity various city-states, in particular Athens, employed them to prevent corruption and violence in election campaigns. In Venice, the doges were elected by a combination of random selection and votes. In some countries, juries are selected by lot, as are the "Planungszellen" in Germany and "Citizens Juries" in the United States and Australia. Many political bodies use the lot in order to reach a decision when there is an equality of votes.

The idea is also rooted in democratic political theory. Aristotle in his Politeia (book 4) even takes the choice of rulers by lot as the only democratic one; he considers elections to necessarily be oligarchic. In Public Choice theory random referenda (Frey 1969), probabilistic models in social choice (Intriligator 1973) and in models of voting by veto (Mueller 1978) have been suggested. An extreme champion of random mechanisms in politics is Burnheim (1985) who wants to abandon elections by voting as the representation of the will of the citizens (Rousseau 1762) altogether. Burnheim discusses several possible

\footnotetext{
${ }^{8}$ As Frey and Stutzer (2000) empirically show, citizens in more directly democratic units are c.p. happier which further activates them.
} 
objections (pp. 164-179). Most of them resonate those raised against direct democracy. Randomly selected citizens are said to lack competence and interest to engage in politics, and they tend to be dominated by experts and bureaucracy. Demarchic bodies are moreover not accountable because its members are not eligible for reappointment ${ }^{9}$.

These arguments against random choice in politics are only partly valid and should be compared to the problems of electoral democracy such as the emergence of a "class politique" pursuing its own goals rather than those of the population, or the restrictive effect of the need for re-election to induce the politicians to act in the interest of the citizens. As has already been pointed out, in countries such as the United States, the United Kingdom, France or Germany election campaigns cost huge amounts of money, and deviate a considerable share of the attention of politicians from problems of great importance to the population. Elections also provide an excellent avenue for special groups to exert undue influence. It cannot be denied that, at least on average, randomly chosen citizens are less educated than average politicians, and perhaps also less interested in political affairs. However, it should not be forgotten that the politicians chosen by lot can use the advice provided by experts and public officials, i.e. they do not need to be technically competent. Their task is to evaluate alternatives in the light of their preferences and life experience ${ }^{10}$. If missing competence was indeed the crucial issue, a democracy such as Switzerland relying on the citizens deciding about all major issues by referenda, would have failed long ago. The opposite is the case ${ }^{11}$. This suggests that the idea of random elements to better reflect the preferences of the population should be taken more seriously than it has been.

\section{What Can we Learn from Gordon Tullock?}

There are three aspects where we can directly profit from Gordon Tullock's way of looking at the world:

- "The world is changing, and politico-economic analysis should be aware of the innovations occurring". Here I have chosen the measurement of happiness and the emergence of digital social networks as examples.

- "Do not be naïve". Innovations do provide new options to further democracy, but it should not be overlooked that, at the same time, they offer new possibilities for governments to manipulate the population. It has here been argued that governments will manipulate the happiness index as well as digital social networks.

- "Seek new solutions". Proposals should be made to go beyond the existing constitutional setting. The government's incentives to manipulate the happiness data and the digital social networks should be restrained by extending the direct political participation rights of the citizens. Random elements should play a larger role in the legislative, executive and juridical branches of government. These changes help the citizens to be better informed, to be more self-confident, and to prevent the emergence of a political class serving its own interests.

\footnotetext{
${ }^{9}$ A useful survey of aleatoric democracy is provided by Buchstein (2009); the relationship to anarchy is discussed in Martin (1995-6).

${ }^{10}$ The German writer Hans Magnus Enzensberger aptly quipped that professional politicians are the only people who never did any serious work; their life consists of sitting in meetings and giving more or less competent talks and interviews.

${ }^{11}$ Switzerland is usually ranked second in happiness rankings (behind Denmark), has a high standard of living, is well organized and is very attractive to immigrants.
} 
This paper has been inspired by Gordon Tullock's example which I am proud to follow but incapable to match.

\section{References}

Benz, Matthias and Alois Stutzer (2004). Are voters better informed when they have a larger say in politics? Public Choice 119: 31-59.

Bernholz, Peter (1991). The Constitution of Totalitarianism. Journal of Institutional and Theoretical Economics 147: 425-440.

Bernholz, Peter (1997). Ideology, Sects, State and Totalitarianism: A General Theory. In: H. Maier and M. Schaefer (eds), Totalitarismus und Politische Religionen. Paderborn: Schoeningh: 271-298.

Buchanan, James M. and Gordon Tullock (1962). The Calculus of Consent. Ann Arbor: University of Michigan Press.

Buchstein, Hubertus (2009). Bausteine fuer eine aleatorische Demokratietheorie. Leviathan 37: $327-352$.

Burnheim, John (1985). Is Democracy Possible? The Alternative to Electoral Politics. Oxford: Polity Press.

Campbell, Donald T. (1976). Assessing the impact of planned social change. Occasional paper No 8, Social Research and Public Policies. Dortmouth College, The Public Affairs Center.

Dolan, Paul, Tessa Peasgood and Mathew White (2008). Do we really know what makes us happy? A review of the economic literature on the factors associated with subjective well-being. Journal of Economic Psychology. 29: 94-122.

Dafflon, Bernard and Sergio Rossi (1999). Public accounting fudges towards EMU: a first empirical survey and some public choice considerations. Public Choice 101(1-2): 5984.

Easterlin, Richard A. (1974). Does Economic Growth Improve the Human Lot? Some Empirical Evidence. In: Paul A. David and Melvin W. Reder (eds), Nations and Households in Economic Growth: Essays in Honour of Moses Abramowitz. New York: Academic Press.

Eichenberger, Reiner and Mark Schelker (2006). Independent and competing agencies: An effective way to control government. Public Choice 130: 79 - 98.

Economist (2011). Politics and the internet. Caught in the net. January $8^{\text {th }}, 74-75$.

Economist (2011). Internet blackouts. Reaching for the kill switch. February $12^{\text {th }}, 61-62$.

Espeland, Wandy M. and Michael Sander (2007). Rankings and reactivity: How pubic measures create social worlds. American Journal of Sociology 113: 1-40.

Forte, Francesco (2001). The Maastricht "Excessive Deficit" Rules and Creative Accounting. In: Mudambi, Ram, Pietro Navarra and Giuseppe Sobbrio (eds), Rules and reason: perspectives on constitutional political economy. Cambridge: Cambridge University Press.

Frank, Robert (1999). Luxury Fever: Why Money Fails to Satisfy in an Era of Excess. New York: Free Press.

Frey, Bruno S. (1969). Wahrscheinlichkeiten als gesellschaftliche Entscheidungsregel. Wirtschaft und Recht 21: 3-15.

Frey, Bruno S. (2008). Happiness: A Revolution in Economics. Cambridge and London: The MIT Press.

Frey, Bruno S. and Alois Stutzer (2000). Happiness, Economy and Institutions. The Economic Journal. 110: 918 - 938.

Frey, Bruno S. and Alois Stutzer (2002a). The Economics of Happiness. World Economics, 3(1): 25-41. 
Frey, Bruno S. and Alois Stutzer (2002b). What Can Economists Learn from Happiness Research? Journal of Economic Literature. 40(2): 402 - 435.

Frey, Bruno S. and Alois Stutzer (2010). Happiness and Public Choice. Public Choice144: 557-573.

Frey, Bruno S. and Margit Osterloh (2010). Evaluations: hidden costs, questionable benefits and superior alternatives. In: Jansen, T; van den Brink, G; Kole, J. Professional pride - a powerful force. The Hague, 175-196.

Frey, Bruno S. and Reiner Eichenberger (1999). FOCJ: Competitive governments for Europe. International Review of Law and Economics, 16(3): 315-327.

Gibbard, Allan (1973). Manipulation of Voting Schemes: A General Result. Econometrica 41(4): 587-601

Goodhart, Charles (1975). Monetary relationships: A new form of Threadneedle street. Papers in Monetary Economics 1, Reserve Bank of Australia.

Habermas, Jürgen (1996). Between Facts and Norms - Contributions to a Discourse Theory of Law and Democracy. London: Polity.

Intriligator, M. D. (1973). A Probabilistic Model of Social Choice. Review of Economic Studies 40: 553-560.

Jacob, Brian A. and Levitt, Steven D. (2003). Rotten Apples: An Investigation of the Prevalence and Predictions of Teacher Cheating. Quarterly Journal of Economics 118: 843-877.

Kahneman, Daniel, Ed Diener, and Norbert Schwarz (eds) (1999). Well-being: the foundations of hedonic psychology. New York: Russell Sage Foundation.

Kern, Holger Lutz and Jens Hainmueller (2009). Opium for the Masses: How Foreign Media Can Stabilize Authoritarian Regimes. Political Analysis 17: 377-399.

Kirchgässner, Gebhard, Lars P. Feld and Marcel R. Savioz (1999). Die direkte Demokratie: Modern, erfolgreich, entwicklungs- und exportfähig. Basel, Munich: Helbing und Lichtenhahn/Vahlen.

Kurrild-Klitgaard, Peter (2000). The Constitutional Economics of Autocratic Succession. Public Choice 103: 63-84.

Layard, Richard (2005). Happiness: Lessons from a New Science. New York: Penguin Press.

Layard, Richard (2007). Happiness and Public Policy: A Challenge to the Profession. In: Bruno S. Frey and Alois Stutzer (eds), Economics and Psychology:A Promising New Cross-Dsiciplinary Field. Cambridge, Mass. and London: MIT Press: 155-167.

Lucas, R. E. (1976). Econometric Policy Evaluation: A Critique. In: Karl Brunner and Alan H. Meltzer (eds), Carnegie-Rochester Conference Series on Public Policy. The Phillips Curve and Labor Markets. New York: North Holland: 19-46.

Martin, Brian (1995-6). Democracy without Elections. Social Anarchism 21: 18-51.

Morozov, Evgeny (2010). The Net Delusion. How Not to Liberate the World. London: Allen Lane.

Mueller, Dennis C. (1978). Voting by Veto. Journal of Public Economics 10(1): 57-75. Mueller, Dennis C. (2003). Public Choice III. Cambridge: Cambridge University Press.

Oswald, Andrew J. (1997). Happiness and Economic Performance. Economic Journal 107(445): 1815-31.

Power, Michael (1997). The Audit Society: Rituals of Verification. Oxford: Oxford University Press.

Rousseau, Jean-Jacques (1762/1937). Du contrat social. Paris: Garnier.

Satterthwaite, Mark (1975). Strategy-Proofness and Arrow`s Conditions: Existence and Correspondence Theorems for Voting Procedures and Social Welfare Functions. Journal of Economic Theory 10: 187-217.

Strathern, Marilyn (2000). Audit Cultures: Anthropological Studies in Accountability, Ethics and Academia. London: Routledge. 
Szpiro, George G. (2010). Numbers Rule. The Vexing Mathmematics if Democracy from Plato to the Present. Princeton and Oxford: Princeton University Press.

Tullock, Gordon (1971). The Paradox of Revolutions. Public Choice 11: 89-100.

Tullock, Gordon (1974). The Social Dilemma: Economics of War and Revolution. Blacksburg: Center for Study of Public Choice.

Tullock, Gordon (1987). Autocracy. Dordrecht: Kluwer.

Ura, Karma and Karma Galay, eds. (2004). Gross National Happiness and Development. Centre for Bhutan Studies.

Van Praag, Bernard and Ada Ferrer-i-Carbonell (2004). Happiness quantified: a satisfaction calculus approach. New York: Oxford University Press.

Von Hagen, Jürgen and Guntram B. Wolff (2006). What do deficits tell us about debt?

Empirical evidence on creative accounting with fiscal rules in the EU. Discussion Papers 148, SFB/TR 15 Governance and the Efficiency of Economic Systems, Free University of Berlin, Humboldt University of Berlin, University of Bonn, University of Mannheim, University of Munich.

Wintrobe, Ronald (1998). The Political Economy of Dictatorship. Cambridge: Cambridge University Press. 